\title{
The legacy of one-room schoolhouses: A comparative study of the American Midwest and Norway
}

Leidulf Mydland

\section{(2) OpenEdition Journals}

Electronic version

URL: https://journals.openedition.org/ejas/9205

DOI: $10.4000 /$ ejas.9205

ISSN: 1991-9336

Publisher

European Association for American Studies

Electronic reference

Leidulf Mydland, "The legacy of one-room schoolhouses: A comparative study of the American Midwest and Norway", European journal of American studies [Online], 6-1 | 2011, document 5, Online since 15 September 2011, connection on 08 July 2021. URL: http://journals.openedition.org/ejas/ 9205 ; DOI: https://doi.org/10.4000/ejas.9205

This text was automatically generated on 8 July 2021.

Creative Commons License 
The legacy of one-room schoolhouses: A comparative study of the American Midwest and

Norway

Leidulf Mydland 


\subsection{Introduction}

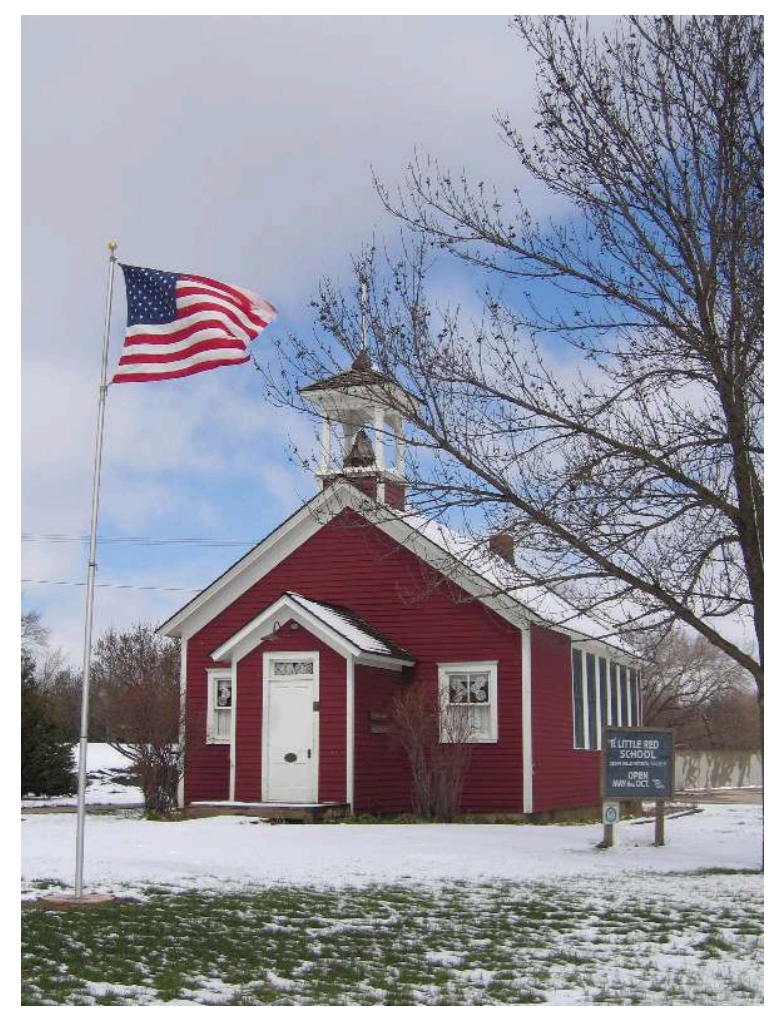

Little red school, Cedar Falls, lowa.

(Photo. L Mydland 2007)

1 The first American one-room schoolhouse I visited was the Little red School house in Cedar Falls, Iowa. The small schoolhouse was originally located in Bennington Township. The new location in Black Hawk Park, the red color, the grand bell-tower as well as the colorful American flag outside the building, made the small schoolhouse visible and significant in the small city. Inside the classroom, in addition to old furniture, maps and blackboards, a huge American flag and pictures of President Washington and Lincoln was the dominant visible element in the classroom. The impression I got after my first experience with an American one-room schoolhouse and how it was displayed was quite different from the conception I had after having seen several one-room schoolhouse in Norway.

2 The definition of one-room schoolhouses is a school consisting of one classroom where a single teacher taught academic basics to several grade levels of elementary-age boys and girls. The one-room schoolhouse is to be found in several countries both in Europe and overseas, but is characteristic for rural areas with sparse population, for example Ireland, Shetland, New-Zeeland, Scandinavia, Canada and Australia. Nevertheless, although the one-room schoolhouse has played an important role in both the American Midwest and Norwegian history, the contemporary European approach, represented by Norway, and the American approach and motivation for preservation differs. The contrast between sixty listed schoolhouses in Iowa and none in Norway needs an explanation. The total number of schoolhouses in Iowa in 1901 was 12,623 which were more than twice as many as in Norway, but the difference in total number does not explain the disparity in preservation. ${ }^{1}$ Neither do the construction, the size, ownership, 
the architectural qualities, demographical changes, if the schoolhouses are standardized or not, the age of the schoolhouse or the location. All these elements are comparable. Differences in legislation and management of cultural heritage could be a part of the explanation, but will not explain the major differences. The reason for the difference has to been found in the cultural background, in the educational history as well as in the need for historical symbols in contemporary society.

Better education was both a goal and a tool in the comprehensive modernizing projects of the nineteenth century, and in many rural communities the school became a trigger for the development of democratic and social institutions. The schoolhouses were in most communities the first public building to be erected, and became an arena for social, political and religious meetings. The school boards were often the first democratic institutions established in the local communities, and played a vital role in the development of democratic society in the late nineteenth century. Last but not least the one-room schoolhouse held notable significance as an institution for education, and represented a shift towards better education and schooling. ${ }^{2}$

4 The history of education has been the subject of comprehensive study in the United States, but one-room schoolhouses as cultural heritage, the narratives of the one-room schoolhouse era, and whether and why old schoolhouses are regarded as an object of interest have so far not been widely discussed. Andrew Gulliford's America's Country Schools was part of the comprehensive research project 'Country school legacy'. However, the author only briefly questioned the contemporary use of schoolhouses as heritage objects. His main goal is to offer a manual for conservationists. ${ }^{3}$

Wayne E. Fuller has drawn attention to the fact that the one-room schoolhouse has 'become so deeply embedded in the American consciousness that today, long after most schools have disappeared, it is still a useful symbol', ${ }^{4}$ but at the very end of his book he reduces the useful symbol to a legacy for young children whereby they can 'appreciate their own comfortable classrooms and be inspired to take advantage of the bounteous opportunities they have to further their education and to be whatever they wish to be'.

6 The lack of reflections about preservation of schoolhouses has been a general tendency in most publications on one-room schoolhouses, with the exception of Jonathan Zimmerman, whose recent book, Small Wonder: The Little Red Schoolhouse in History and Memory, comments on the use of schoolhouses in current political battles.So far it has not been possible to identify any publications in Norway dealing with this issue, and in the existing publications the reason for preservation is often limited to passing on a rich heritage to future generations. ${ }^{5}$

7 The intention in this paper is not to carry out a comprehensive comparative study of the one-room schoolhouse era in the US Midwest and Norway, nor to do a wide survey of the heritage field in these two countries or a deep social analysis of Norwegian and American attitudes. In this paper I will show how two different societies, the American Midwest and Norway, deal with rural education as history and one-room schoolhouses as heritage objects. The objective of this comparative study is to show that what at first sight seems identical - the objects of cultural heritage themselves - in fact reflects difference attitudes to the past. An examination of the motives for preservation reveals the ideological and political reasons for spending money, time, and energy of volunteers on preservation of schoolhouses. My intention is not to promote some new argument for the preservation of schoolhouses, but by the comparative study to show two different approaches to these issues lead to contrasting heritage strategies. 


\subsection{Empirical material: theoretical and methodological approach}

8 My theoretical approach to the issue implies that significance, heritage value assessment and chosen narratives are a social construction dependent on the purpose which the story or the heritage object is intended to have. ${ }^{6}$ The different ways we choose to tell the story of one-room schoolhouses reflect differences in the two societies under examination, differences that describe various values and virtues and the different aims of the preservation of built heritage. The written and spoken history of education, preserved schoolhouses and public school museums are not reflections of a true history, but a selection, interpretation and even construction made to fit our contemporary need and our comprehension of the past. Similar approaches have also been applied by researchers dealing with schoolhouses such as Jonathan Zimmerman: 'We tailor the past to serve the present, all the time. But Americans are probably more likely to do it when they encounter an icon like the little red school house; which is so widely shared and loved'.

9 Such quotations are in line with the social constructivist theoretical approach applied in my research. This implies that in the presentation of the historic setting I will neither question whether the statements in the books and papers are 'historic facts' nor examine the sources used in these books. Instead my intention is to show how similarities and differences in the perception and interpretation of the one-room schoolhouse era occur in the popular literature and official and institutionalized documents, and finally in the way the two societies choose to tell the one-room schoolhouse story.

10 My empirical material consist primarily listed schoolhouses in the archives of the State Historical Society of Iowa, and the listed schoolhouses in Wisconsin, widely distributed books, publications promoted through the Country School Association of America (CSAA), and publications in the libraries of the Iowa and Wisconsin Historical Societies. By no means is my sample of literature meant to cover the entire one-room schoolhouse story, but it is fair to say that the selection is representative of the large amount of schoolhouse literature.

\subsection{The schoolhouse}

Small one-room schoolhouses are still visible in the rural landscape of the Midwest and Norway if you know what characterizes these often anonymous buildings. To show how common and widespread this institution was, some statistics are useful. Altogether more than 200,000 one-room schoolhouses were built in the rural areas of the USA, mostly in the Midwest, where more than 90,000 of these quite simple buildings were erected.In Norway more than 5,200 schoolhouses were built between 1860 and 1920 . The Midwest had a rural population of approximately 17 million inhabitants in 1920 whereas the rural population in Norway at the same time was 1.4 million: that means, at the beginning of the twentieth century, one schoolhouse for every 188 inhabitants in the Midwest, whereas rural Norway had one schoolhouse for every 340 inhabitants. ${ }^{8}$ 
12 In the US, the schoolhouses developed from simple log buildings built by the first pioneers to the typical balloon-framed, wooden-sided, white-painted one-room schoolhouses that could be found in profusion in the Midwest in the early twentieth century. Although most schoolhouses in fact were white, the term little red schoolhouse' has been commonly used for these buildings. The first schoolhouses were built by local farmers according to local building traditions. ${ }^{9}$ Although a number of architect sketches of schoolhouses were made in the second half of the 19th century, contributing to the establishment a well-defined architecture, most farmers built their schoolhouses according to local tradition, but inspired by neighboring schoolhouses. ${ }^{10}$ Sometimes the schoolhouses were given simple decoration on the front, and in the late nineteenth century a bell-tower was often added. The schoolhouse usually consists of one classroom, windows on either one or two walls, a simple entrance on the front side and in rare cases added cloakrooms or a vestibule. ${ }^{11}$ Although there was some variety in design, materials and building traditions, the result was a collection of relatively homogeneous structures, whose conformity is merely a result of form following function.

13 Studies of Norwegian schoolhouses show more or less the same picture. ${ }^{12}$ Local farmers built the schoolhouses according to local building traditions. In 1863 the Norwegian government printed sketches which were meant to be used by local communities, but so far no schoolhouses based on these instructions have been found. In 1886 the government once more drew up new guidelines for schoolhouses to ensure better schooling conditions. This led to a new generation of schoolhouses with larger windows, placed side by side, and after a while the schoolhouses developed from anonymous buildings to typical schoolhouses easy to distinguish from other buildings. There are some minor differences between the Norwegian and the Midwestern schoolhouses. Bell-towers never occur on Norwegian schoolhouses, and the entrance is usually on one of the long sides of the building, seldom on the gable end, as in the Midwest. In Norway there is always a vestibule or cloakroom, and often a separate room for the teacher. There is a general lack of decoration on the Norwegian schoolhouses, with the exception of a couple of schoolhouses erected in the late nineteenth century that were sparsely decorated in accordance with the new late Victorian style, with wooden ornaments around the windows and on the gables.

14 In the early twentieth century the schoolhouses in Norway became more standardized and the local variations vanished. This was partly a consequence of regulations, but more a general pattern where uniform modern architectural design was spread in all corners of the country. ${ }^{13}$ It is more difficult to see standardization of the schoolhouse in the Midwest, but there is a general tendency of putting more effort into design and embellishment in the late 19th century. Both in Europe and the US local vernacular variation faded in favor of a new widespread homogeneous design. From an architectural point of view one can see some minor differences in shape, construction and function, but the majority of schoolhouses in Norway and the Midwest do not represent an outstanding architectural achievement. As a group they represent a humble group of architecture.

15 Although there are some minor differences in the architecture and building construction between the Norwegian and Midwestern schoolhouses, and some variations in the climatic conditions, the variety does not explain the different fortune of the schoolhouses, neither the suitability for any kind of future use nor the possibility 
of preservation. The different approach to preservation has to been found elsewhere, most importantly in the contemporary culture within which the schoolhouse existed.

Although the Scandinavian population in the Midwest was substantial, the footprint of the first generations of immigrants in the second half of the nineteenth century is difficult to spot in the history of education and in the schoolhouse architecture - partly because the Norwegians did not bring with them an established tradition of public education When the new Norwegian school law was under construction in the 1850s, agents of the Norwegian government were sent to North America to collect information about the well-functioning education system in the US. ${ }^{14}$

During the late 1930s and in the 1950s and 1960s, most of the one-room schoolhouses went out of use, both in the USA and Norway, owing to consolidations, demands for better education and better means of transportation. When the schoolhouses were built in the US and Norway, they were located within walking distance of the pupils' homes, but after World War II the location of schools was merely dependent on how far it was acceptable for pupils to travel by bus. The thousands of redundant schoolhouses were sold, torn down, given to the local community as meeting-houses or often just abandoned.

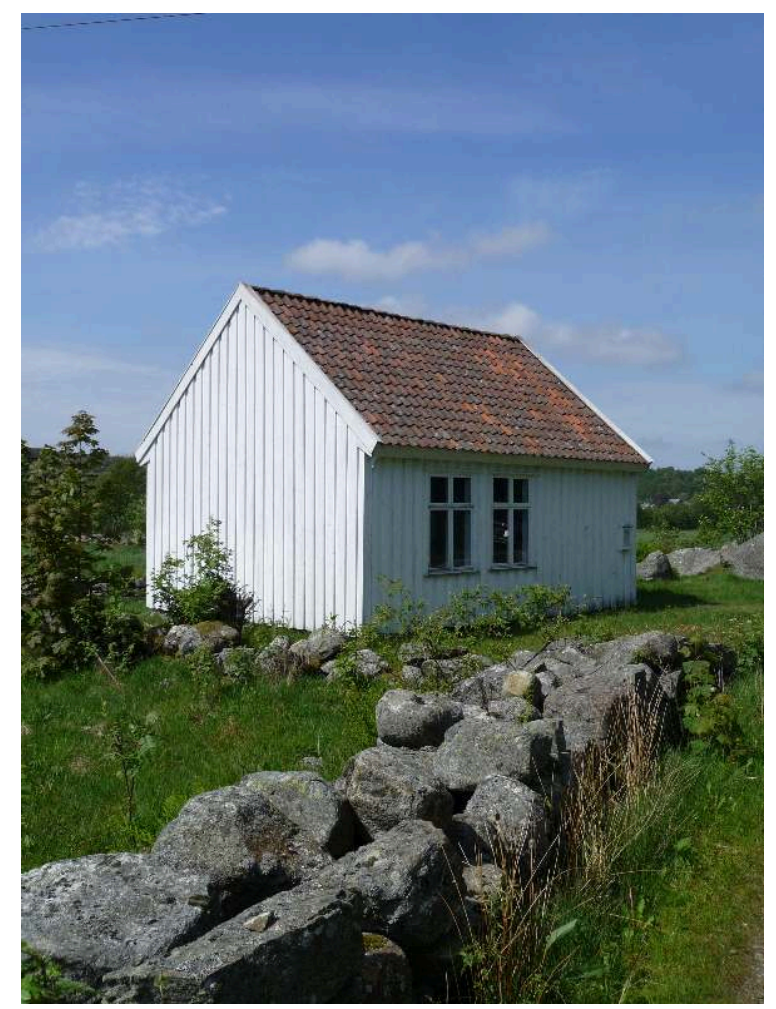

Hesthammar School in Norway.

(Photo. L. Mydland 2009)

\subsection{School reform in Norway: motivation and resistance}

The nineteenth century was a period of social, economic, political and cultural development in the new and old worlds alike. Both in the Midwest and in Norway the 
majority of inhabitants lived in rural areas. The second half of the nineteenth century was a turbulent period in Norway. The country was united with Sweden, but had its own government. Economically and socially, it was a time of change, people moving from rural areas to areas with industrial development. When the old traditional farming and fishing communities met the new economy, social and cultural realities altered. People had the opportunity to choose whether to stay or to move. They could even join the hundreds of thousands of migrants who had decided to head for the Promised Land in the west.

The educational development in nineteenth-century Norway represented a shift from illiteracy to basic knowledge in terms of the three 'Rs', reading, 'riting, and 'rithmetic. The educational system in rural areas in the first half of the nineteenth century was poor, and permanent school buildings were rare. The first Norwegian legislation regarding education, dating from 1739, was initiated by the Lutheran Church to prepare children for confirmation. Most of the schooling activities were carried out in private homes which gave this institution the Norwegian name omgangsskole because the teacher moved from house to house during the year. ${ }^{15}$ After finishing the omgangsskole, quite a high number of children were still illiterate - but they could recite the catechism by heart.

The comprehensive school reform in Norway in 1860, consisting of better teacher training, a wider range of subjects, more school hours and better educational books, was part of a political movement. It both reflected and supported the social and economic changes of the second half of the nineteenth century. As a consequence of the reform, communities where at least 30 pupils could walk to school every day were obliged to build permanent schoolhouses in each of the newly established school districts. The intention behind the school reform was to strengthen the education system and to establish common, democratic institutions, locally-based but national in terms of their organization.

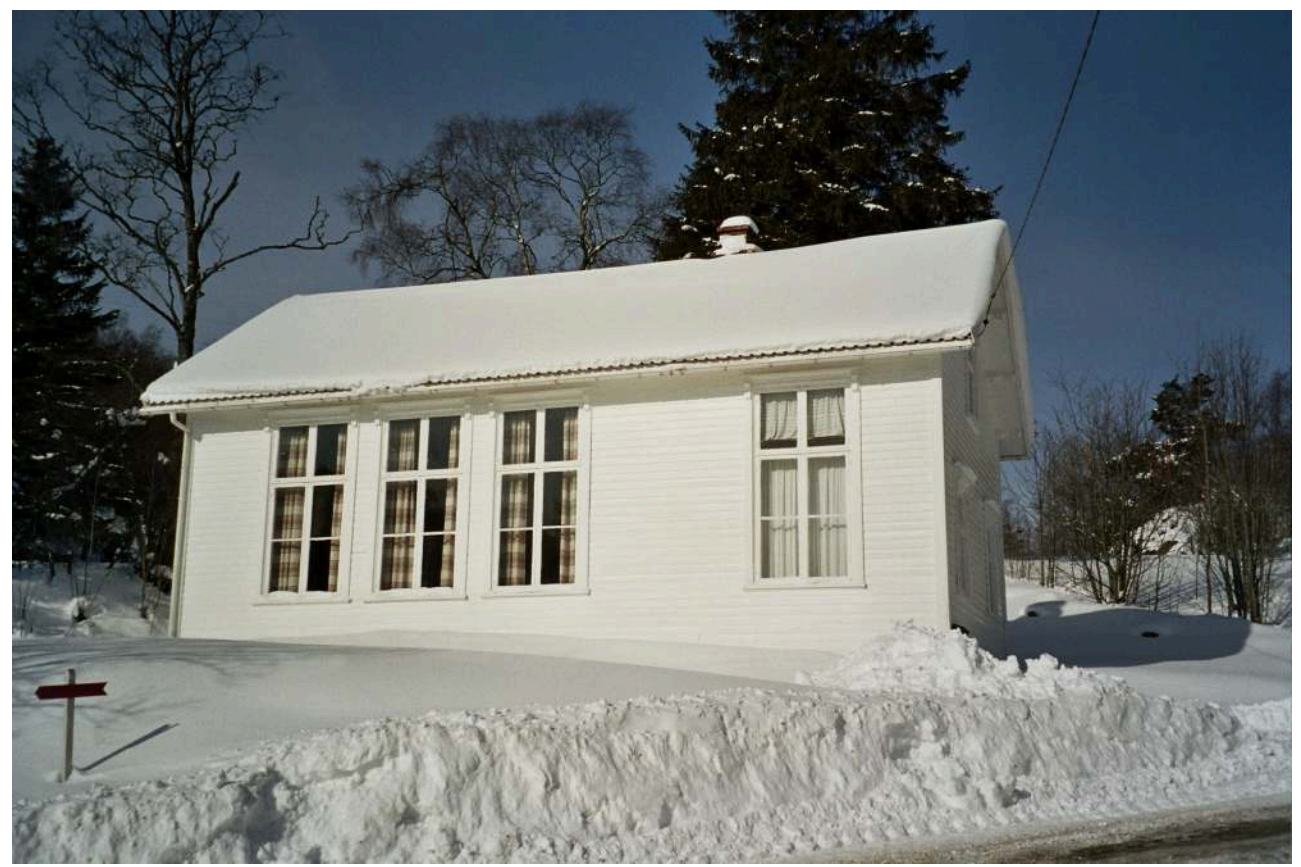

Slåta School, Flekkefjord. Norway.

Photo, L. Mydland 2007. 
21 anxiety for changes, new taxes, skepticism about governmental direction, and finally, yet importantly, strong religious conservatism presented obstacles to school reform. The traditional home-schoolingwhere parents could watch over their children's education was preferred to sending children to a schoolhouse where a teacher was in charge.The new school legislation was therefore not welcomed in all regions and local communities, and in several parishes the inhabitants obstructed the reforms. Opposition to the school reforms was strong until the very end of the nineteenth century, and in some areas, as late as $1890,48 \%$ of the parishes still had homeschooling, where children often used the New Testament as their reader. ${ }^{16}$

drive for educational reform in the mid-nineteenth century was found first and foremost among people and organizations with progressive political views; academics, and people concerned with modern development. They saw education as an essential premise for establishing and developing a democratic nation, a matter of necessity in the new modern society. Some more conservative groups supported school reform as a tool to prevent labor-class activities and the growth of sectarian congregations, believing that a public education system would guide these people back to civil fellowship and the established church.

Although the law delegated the establishment of local schools and local school boards to the local communities, the curriculum, the training of teachers and the school as an institution were directed by the government. The great geographical and cultural diversity of Norway was only to a limited degree reflected in education, its organization and its content.

\subsection{The motivation for establishing schools in the American Midwest: building a nation}

The land ordinance of 1785 governing the vast areas beyond the Appalachians provided that governmental land should be divided into townships and sections. Usually, section number 16 was set aside to support education. The revenue from this section formed the nucleus of an educational fund that allowed the creation of a system of public education. The late nineteenth century, the post-civil war period, represented an era of modernization in the development of the US, including the establishment of a federal bureau of education, and little by little compulsory attendance laws in the second half of the nineteenth century. The responsibility for school and education in the US was largely a local affair at the turn of the twentieth century, and the federal government had no involvement in primary and secondary education. ${ }^{17}$

In the majority of the examined literature the consolidation of the new-born state and simultaneous expansion into the west, together with the establishment of new settlements in the nineteenth century is the backdrop for the establishment of schools. Several authors have stressed that the motivation for putting emphasis on schools and education in the Midwest was because it was an essential part of establishing the new nation and therefore the future. 'The country school fulfilled Jefferson's dream for an educated common citizenry without which democracy would not be able to thrive'. The new-born United States was fragile, populated by immigrants of different languages, cultures, and faiths, many of whom were unfamiliar with the requisites for self- 
government. The future of the nation depended on the new states, often termed the Wild West, being Christianized and imbued with republican values. There was a general agreement among Americans that some measure of homogeneity was needed to forge a unified nation and a suitable tool to this end was a public school system. In One Room Country Schools of Kansas, Bill Samuelson emphasized that one-room schoolhouses were essential for building the economic, social, political and cultural foundation of the state and William H. Dreier observed that the need for country schools was never hard to document and was accepted by people, who responded by building thousands of schools. ${ }^{18}$

Most literature addressing the one-room schoolhouse era in the Midwest places emphasis on the willingness to build schoolhouses and the concern for education. Some studies, however, have shown that there was often a lack of support for new and better education. The future for children lay in the traditional farming community and literary knowledge was not considered as necessary. Many children even suffered under ill-trained teachers in buildings where not even a 'self-respecting farmer would have kept his cows' ${ }^{19}$ Nevertheless, the majority of authors of popular literature dealing with education in the Midwest tell a story of shared willingness to put emphasis on education and to establish schools as common, democratic institutions, and this idea was shared by the central government and local communities. The local staffing and funding are important aspects to understand the role of education and the significance of the one-room schoolhouse era. However, most publications emphasize the national significance of establishing schools and improving the standards of education.

The Norwegian school reform was implemented in the second half of the $19^{\text {th }}$ century as part of the modernization project which encountered resistance from a large part of the conservative rural population. In the American Midwest the new schools were part of the nation building, an effort to unifying the country in which the schools became important symbols for a shared project.

\subsection{The schoolhouse as a heritage object}

'Country school: One room - one nation' is the title of a film made by American film makers Kelly and Tammy Rundle in $2008 .{ }^{20}$ Part of the text on widely distributed promotional postcards reads:

country school as an American architectural icon, is as imprinted on our perception of the nation's early history as the log cabin or the general store.

Country school: One room - one nation tells the dramatic true story of Midwestern country schools and their impact yesterday and today.

In these texts the one-room schoolhouse receives a significant role in American history and has an impact even today. Although the majority of American one-room schoolhouses are demolished, the number of books and papers dealing with the history of rural education and one-room schoolhouses in the Midwest is large and growing. A search on the internet gives more than 9.4 million hits on 'one-room-schoolhouse'. Organizations such as the Country Schools Association of America (CSAA) have been established to promote the preservation of one-room schoolhouses. In books published in the US, the one-room schoolhouse is referred to as 'a beloved national icon' or a 'small wonder'. ${ }^{21}$ The one-room schoolhouse is furthermore displayed on the 25 -cent piece of Iowa, on Christmas decorations, and in many paintings copied nationwide, 
including paintings by Grant Wood and Winslow Homer. In 2002 several one-room schoolhouses were erected in front of the entrances to the Department of Education in Washington to promote the campaign 'No Child Left Behind'. A lot of schoolhouses are also preserved and displayed in public museums or used as schoolhouse museums either in their original location or moved to suitable places, often fairgrounds. ${ }^{22}$

The Pine-Strawberry Archaeological \& Historical Society in Arizona has produced a travellers' guide to the USA's one-room schoolhouse museums which contains information on more than 80 one-room schoolhouse museums open to the public. ${ }^{23}$ The school museums are distributed in 50 states. A web search also gives hundreds more matches for one-room schoolhouse museums in the US. In addition more than 42 schoolhouses are situated on college and university campuses where they are in use as museums, for education, meeting-places, campus classes, polling stations and special programs. $^{24}$

31 Just a dozen school-house museums were visited by the author in Iowa and Wisconsin, but the impression they give is more or less the same. In addition to old furniture and simple educational equipment, the classrooms often exhibit pictures of the American national heroes, Washington and Lincoln, on each side of the American flag. Before 1890 there was, in both the US and Norway, a general lack of symbols and pictures in the classroom, but by the end of the nineteenth century, in a period of heightened national patriotism in the US, symbols reflecting American patriotism were brought into the classrooms. At the same time the Pledge of Allegiance was written (1892) and the text often placed at the front of the classroom, where it can still be seen together with replicas of historical documents.

\subsection{Listed schoolhouses: motivation and significance}

Approximately 60 Iowa schools are individually listed on the National Register of Historic Places (NRHP). ${ }^{25}$ In my survey, 20 listed one-room schoolhouses in Iowa were examined. The first school listed in Iowa was Branch School in Cedar County, listed as early as 1966. The main reason for this was that it was assumed that US President Herbert Hoover (1929-1933) had attended the school. It was also mentioned that restoring, refurbishing and interpreting the schoolhouse was meant to provide visitors to the site with an insight into the intellectual values and standards of achievement of primary education in the 1870s. In the 1970s seven more schools were listed. ${ }^{26}$ In the statements of significance for these schoolhouses, there is a general tendency to emphasize the school as representative of the thousand one-room schools and their relevance for the history of education.

In the 1980s and 1990s some new arguments appear in addition to those mentioned above: 'The importance of the country school to socializing on the often isolated life of rural Iowa settlers', and 'a reminder of early educational practice and community involvement'. ${ }^{27}$ These examples reflect an increasing focus on the importance of the schoolhouse as a common institution which has a broader significance than just that of teaching.

The ethnic dimension appears for the first time in the 1990s. When Jackson \# 1 School in Shelby County was listed in 1990, the Danish affiliation was emphasized. When Monona School was listed in 2001, there was still a focus on education, social history 
and architecture in the statement of significance, but more interesting in this context is that it is now mentioned that the Danes built their own school. ${ }^{28}$ Finally, theWalnut Grove School in Mitchell County was listed in 2002, and here as well it is emphasized that the schoolhouse was built by Norwegian settlers in 1857 .

My survey of listed schoolhouses in Wisconsin assessed all 20 individually listed schoolhouses. ${ }^{29}$ The first one-room schoolhouse listed was 'The little white schoolhouse' in Ripon, Fond du Lac County. The building was recognized in the National Survey of Historic Sites and Buildings for its historical significance and was deemed worthy of entry in the National Register in 1973. The reason for this was purely that this building was the birthplace of the Republican Party in 1854. The next schoolhouse listed in Wisconsin was Frances Willard Schoolhouse in Rock County. The school, originally named Willard School, was listed in 1977 because the social reformer Frances E. Willard (1839-1898) was the most famous person who ever lived in Rock County. In the value assessments it is also mentioned that the schoolhouse is of local importance as an example of a very early one-room schoolhouse and one of the oldest school buildings standing in Rock County. One year later, in 1978, the Old Rock School in Iowa County was listed as a significant example of nineteenth-century Cornish masonry work indigenous to the Dogerville area, and also because it was the remaining schoolhouse of two built in 1853 and was significant in terms of local educational history.

In the 1980s five more one-room schoolhouses in Wisconsin were listed. The first one, Ward District \# 3, was listed in 1981 because Earl Baker, United States Commissioner on Rural Reconstruction in China, had attended the school. In the same year, Smith Valley School in La Crosse was listed. Now a series of new arguments emerges. The significance and role of the school for the people in the area, both for meeting and education, is put forward and it is also stressed that the school continues to be a focus of community pride because of its fine state of preservation.

Also, in the argument for listing the Ephraim School in Door County, the school's significance for education in Ephraim and the county's attempt to improve the school system were stressed. The two other schools listed in the 1980s were listed primarily owing to their architectural significance. In the 1990s eight more Wisconsin schoolhouses were listed on the NRHP.

Three more schoolhouses have been listed since 2000. It is quite interesting to see that the main focus is again on aspects such as typical, fine example and integrity, related to the building as architecture, and some minor additions concerning the role of the school in the development of education.

In general the argument for listing buildings became more comprehensive and distinct in the more recent listings, and a variety of arguments are adduced in addition to the traditional ones on architectural and educational history. The general focus on architecture is still present, but the social role in the local community receives more emphasis.

40 The argumentation and the criteria for listing schoolhouses have changed since the first examined schoolhouse were listed in Iowa in 1966 and 1973 in Wisconsin. The first generation of schoolhouses is listed due to their connection to famous historic persons or major historic events, but even schoolhouses listed in the 1980s are listed mainly for this reason. As shown both in Iowa and in Wisconsin, several schoolhouses are listed because famous persons attended or allegedly attended them. It does not seem 
necessary for the important person to have had special experiences in the schoolhouse or later any influence on the school's history. As regards the Herbert Hoover site there is even a question of whether Hoover actually attended the school.

The next generation of schoolhouses entering NRHP is listed primarily due to their significance for education and socializing the local community. Now elements such as the community's sentimental association with the building occur in the value assessment. When Laney School, Shawano County, was listed in 1998, the following statement was filed: 'Community pride in and identification with the building springs from this combination of features; by incorporation much of the educational, social and civic aspects of the community, the Laney School played a significant role in the life, development and identity of Lane Community'. ${ }^{30}$ An interesting feature of this generation of listed schoolhouse is also the ethnic dimension that first occurs in the 1990s. What was originally a "national" project gathering all immigrants in a common school, has first as an object of cultural heritage included the diversity of different nations.

For the last group of schoolhouses enrolled on the national list there is a tendency to emphasis style, design and embellishments, often mentioned as architecture. The focus on architecture, design and embellishment and the word typical are observable from the 1970s until today, together with attention to the role and development of education in rural areas. This reflects the emphasis on architecture in the information issued by the State Historical Society of Iowa.

In a booklet published by the Country Schools for Iowa, the National Register Criteria for Evaluation is referred to which stresses four important elements. ${ }^{31}$ Schools may be eligible for listing in the National Register (NRHP) under the following criteria. (A) For their association with the development of the rural educational system in Iowa. They can also establish under this criterion their importance as a social center for rural communities in Iowa. (B) Schools that were directly significantly associated with individuals who played an important role in the development of education in Iowa. (C) As an example of a distinctive building type - the country schoolhouse - because of their universal form - a one-storey, gable roof structure with double-hung windows on the sides and an entry on the gable end. (D) Describes sites of former schoolhouses that have not been physically disturbed and may yield important archaeological information about school construction and activities.

On the web page for the State Historical Society of Iowa some additional questions are asked to determine whether the school is eligible for listing on the NHRP. Is the school old? Does it have architectural embellishments, such as round windows or doors, a cupola or other unusual features? Can it be linked to a known plan book design? Does the school have an unusual design? Was the school designed by a nationally prominent architect? Is the school one of the early consolidated schools? Was the school the location for significant historic events? Was the school an addition to the schools built under the New Deal-era funding for labor? It is interesting to note that several of these terms focus on architecture and design.

The examination of listed schoolhouses, the examined literature and the above mentioned publication from Iowa show some interesting patterns. The motivation for listing schoolhouses could be categorized into four major groups: Celebrity or major historic events (the latter often related to famous persons), social and cultural history (including history of education and community celebration), architecture (including 
style, example of a distinctive and typical schoolhouse type) - and finally identity and symbolic value (not explicit in official documents). It is interesting to note that there is an increasing tendency to emphasize architecture and stylistic aspects as motivation for preservation, especially within the authorized heritage authorities. Architectural Historian and Deputy SHPO in the State Historic Preservation Office in Iowa, Barbara A. Mitchell, have commented on the significance of the schoolhouses. She mentions that in addition to their association with public education and their architectural style, the significance for most Iowans lies in the 'shared history, community identity and architectural legacy'. ${ }^{32}$ The words shared history and community identity perhaps correspond best to the content in the beloved icon and reflect that the value itself is not the actual schoolhouse, nor the history of education - but primarily a symbolic identity for citizens.

\subsection{The schoolhouse as heritage in Norway}

The brevity of this chapter compared with the previous chapter reflects to a certain degree the different value assessments of the Midwest and Norway. So far not a single, rural one-room schoolhouse has been listed on the Norwegian equivalent to the NRHP, ${ }^{33}$ despite their value as historic monuments reflecting the nation's educational history. It is difficult to compare the preservation of schoolhouses in the US and Norway owing to different legislation and differences in the management of historical buildings. A list of buildings such as the NRHP does not exist in Norway, but the Directorate for Culture Heritage (Riksantikvaren) can by law protect buildings and settings to prevent the private owner of a protected house from knocking it down or changing it. More than 5,000 buildings are protected by law in Norway, which is quite a high number considering the small population. Although the tools exist, so far none of the 5,200 oneroom schoolhouses built in rural areas after the school reform in 1860 has been listed or is protected by law. In contrast, fifteen school buildings in the big cities have been protected by law.

47 Famous persons, major historic events, social and cultural history including the history of education were the major motifs for listing schoolhouses in the US. These motifs are difficult to spot in the Norwegian material, as are identity and symbolic value. A general pattern for the protected school buildings in Norway (not one-room schoolhouses) is that significance is associated with style, architecture and monumentality, reflecting the Authorized Heritage Discourse (AHD). ${ }^{34}$ Only in one case is a school building protected because of its role in the history of education. 


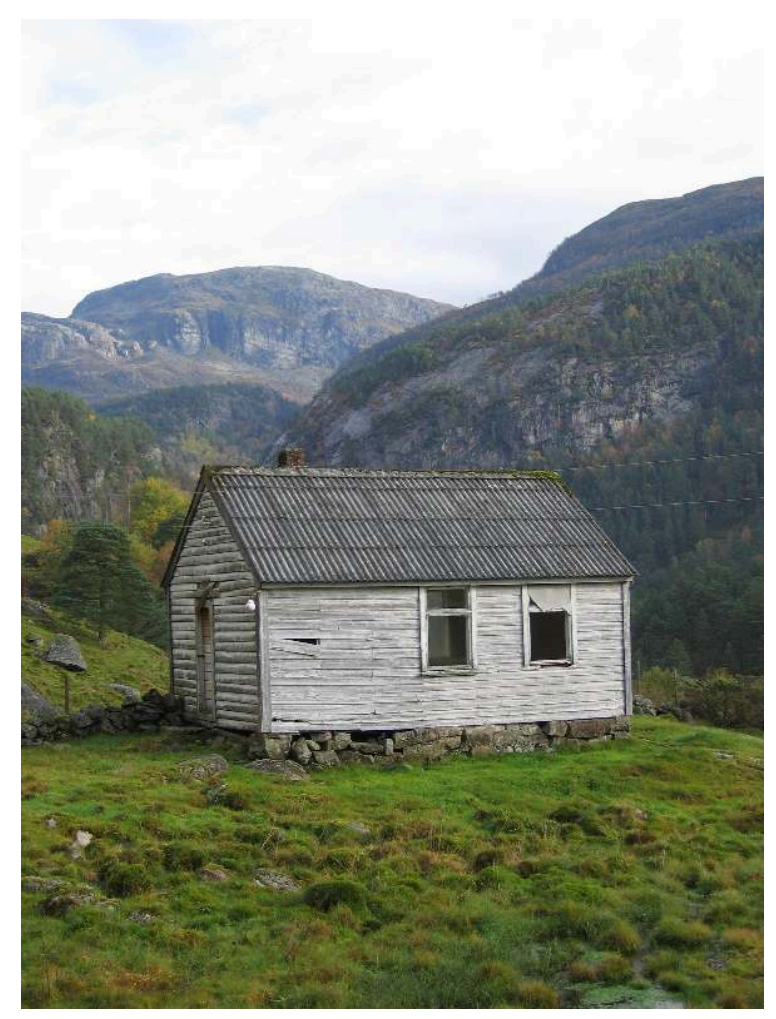

Nedre Fjedle skole, Suldal Norway.

Photo taken in 2007, demolished in 2008.

Photo L. Mydland)

The existing literature on educational history in Norway is not extensive, and there are few books dealing with the one-room schoolhouse era in particular. Most titles deal with the general history of education, from the first schools in medieval times to the modern education system. The school reform of 1860 and the one-room schoolhouses have so far not been given special attention. The one-room schoolhouse era is not emphasized in the many local history publications. Most of these papers deal with the history of education and only a few mentions the schoolhouse as a historic building; there are no reflections on value and significance..$^{35}$ Even though many local school districts resisted the new school-reform and the request for building schoolhouses, these conflicts are not given major attention in the local literature.

In spite of the absence of listed schoolhouses in the records more than 100 schoolhouses are preserved in local or regional museums in Norway. Most school museums are local initiatives and serve only their local communities. Most of these museums were established between 1960 and 1990, a period which witnessed some enthusiasm for local history. ${ }^{36}$ As part of school anniversary celebrations in 1989, local communities were encouraged to establish local school museums and the same time several one-room schoolhouses were moved to regional outdoor museums. Although a large number of schoolhouses are preserved as local school museums or have been moved to regional open-air museums, these buildings are seldom among the buildings chosen for guided tours, and quite often they are not open or on display to visitors.

50 A study performed by the author in 2009 shows that the story told in these schoolhouse museums is a story of how primitive everything was in the past, and how simple and poor the schools were before modernity saved us.The study also revealed that there 
was a general absence of narratives about the great achievement of building 5,200 schoolhouses 150 years ago.

51 The high number of listed schoolhouses in the Midwest, and the emphasis on the school as a symbol of the nation, is characteristic for the US. In Norway and probably the rest of Europe, the school's first of all have been given attention if the building itself reflects outstanding architecture or high age. The school as an object of heritage with high national symbolic values, reflecting education and the development of the nation is unknown in Europe, so far as this author can see without carrying out a comprehensive survey of listed schoolhouses in Europe. To refer to the simple schoolhouse as a "national icon" is therefore probably unique for the US.

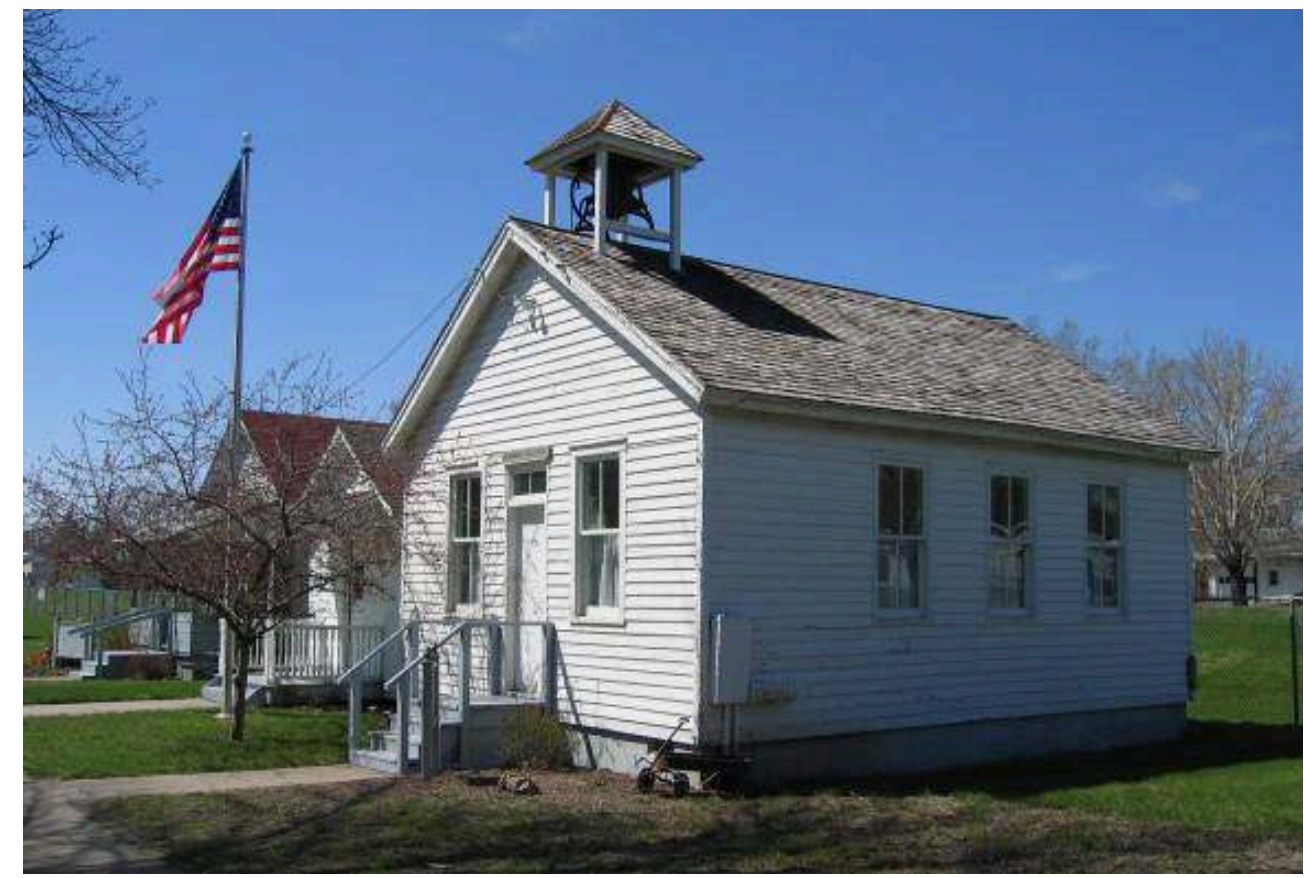

Summit School "Straw College", in Historical village of Kalona, lowa.

(Photo, L.Mydland 2007)

\subsection{The historical background: some differences and similarities}

The schoolhouses in Norway and the American Midwest were built more or less simultaneously for similar educational purposes, but the meaning attached to these buildings differs much. The literature in the US focuses to a high degree on education as part of establishing a new society, especially in the Midwest. The American literature also stresses the willingness of people in the rural areas to build schoolhouses and the fact that public schools became both an instrument for establishing the new societies and a meeting place for scattered populations. The literature also observes that establishment of schools, staffing, funding and building the schoolhouses were the result of local organization without central intervention. This made the schools acceptable, even vital in the local communities. The resistance to new school reforms in the Midwest, how schools under the supervision of local school boards reproduced the 
prejudice of small communities, poor schools without sufficient heating, blackboards and textbooks, and unfair teachers all seem to be forgotten elements and are seldom mentioned in the American publications. This result shows how the story of one-room schoolhouses is perceived and interpreted.

In Norway the picture is different. The existing literature tells the story of how central government and the cultural and social elite promoted better education in urban and rural areas, despite resistance from parts of the government and advocates of a reactionary policy and last but not least the people in local communities who did not want changes at all. ${ }^{37}$

In contrast to the Midwest, where the school was a feature in the newly established settlements, the schools in Norway were established in an existing society, mostly consisting of conservative farmers. To promote the new legislation the government gave the local communities and local school boards wide authority, but used financial support to encourage good standards. The support was dependent on how much the locals were willing to pay themselves. The new regulations also set national standards for the curriculum and teachers' qualifications.

Although the local one-room schools in Norway gradually became an integrated part of local society, new regulations and instructions from central authorities and finally the closure of the local schools in the mid-twentieth century weakened the links between the local communities and the schools as an institution. Both the establishment of permanent schools in 1860 and the closure of the same schools a hundred years later caused resistance in many local communities. This conflict between central government and the local community could be seen as part of the on-going tension between them, described by Stein Rokkan as the 'centre-periphery structures', an approach still relevant in explaining impetuses in political society. ${ }^{38}$ The tension between the local and the central government could perhaps explain why the schoolhouses in Norway never have become an important object of cultural heritage; the governmental heritage authorities regard the one-room schoolhouses mainly as objects of local interest, and the locals regard the history of education as a part of the central government affairs.

56 The differences between the late $19^{\text {th }}$ century Norwegian and American Midwest culture and socio-political structure are considerable. Norway did not share the widespread support and encouragement for education by the US government, the general optimism regarding the establishment of a new society in the US and the willingness among most of the local communities to prioritize education. The terms "the new and old world" in the light of school and education, is striking. But more interesting than historic points of distinctions is the difference in the contemporary approach to the history and the national narratives. While the history of the American nation, the first president, the constitution and last but not least the flag, is present in most of the school-house museums in US, the national project in Norway is not a part of the narratives of the Norwegian school museums, it is even difficult to spot other stories than those concerning how primitive the past was compared to the present.

\subsection{Virtues and values}

The school as an institution for establishing and maintaining a set of national common values is well documented in previous research in both an American and a Norwegian 
context. ${ }^{39}$ The one-room schoolhouses in the US have been in focus at several times, characterized as a national icon, and have always been given a sense of meaning by someone. ${ }^{40}$ The schoolhouses were initially a symbol of the new-born state and the willingness to establish new local societies and progressive education, and later became a symbol of what was wrong with education and what had to be changed, a symbol of local democracy and involvement, or a symbol of the prejudices of small local communities, intolerance and conservatism. Both Democrats and Republicans have taken the schoolhouse to their hearts and even the anti-communist movement in the 1950s used the (red) schoolhouse in its propaganda. ${ }^{41}$ Zimmerman stressed that the one-room schoolhouse reflects different values for people with different political affiliations, a variety of organizations and movements. The schoolhouses '...connect Americans to a shared past, even as they embellish - or ignore - various aspects of it. Indeed, despite Americans' many differences, the little red schoolhouse might be the only icon that can bring them together'. ${ }^{42}$

Although the schoolhouse as a heritage object reflects different values for different people, it is still a common symbol of a shared past, a symbol carrying values to fight for or against. In a period when American values and patriotism are being revitalized, the one-room schoolhouse once more seems to be the focus of people and organizations promoting preservation of these buildings - and some of the values these buildings represent.

59 In the large number of books addressing the one-room school era in the American Midwest, one topic is often given special attention; the virtues and values attributed to the schoolhouse. In the introduction to One-Room Country Schools: South Dakota Stories, the editors write: 'Rural life is the legacy of the state of South Dakota, and the foundation of this legacy is the one-room country school. Even today, long after most have disappeared, the one-room country school remains the nation's most enduring symbol of education and the traditional values of Euro-American society'. ${ }^{43}$

60 In Icons of America, Schroeder gives another example of the virtues and values attributed to the schoolhouse by drawing attention to the Little Red Schoolhouse as a symbol of equality, whereby the teacher inculcates young Americans in the homegrown values of independence, self-reliance, democracy and simple rural virtues. In the foreword to The One-Room Schoolhouse by Rocheleau, one reads that the schoolhouses 'rose like a buoy of learning in a sea of ignorance'. In the preface to Iowa's Country Schools, Landmarks of Learning, William Shermann spoke of one-room schools as being landmarks of learning and his book is dedicated to the '..thousands of men and women who taught in Iowa's one-room schools. Their hard work and sacrifices provided generations of students with educational experiences which helped them become productive citizens and helped Iowa achieve the highest literacy rate in the nation'. ${ }^{44}$

61 In America's Country Schools, there is a note from the former US First Lady, Barbara Bush, who places emphasis on both the educational history and the important role the school played in the new democracy and in local communities. In addition she noted that the children '...learned a curriculum steeped in such values as honesty, industry, sobriety and patriotism - values we all cherish'. ${ }^{45}$

62 All the words used in these quotations - independence, self-reliance, democracy, honesty, industry, populist spirit, sobriety, patriotism, simple rural virtues, equality, productive citizens, landmarks of learning -express concepts reflecting virtues and values that most American people, at least in the Midwest, still appreciate. 

the fact that the new school reform in 1860 was a premise for social, cultural, democratic, political and economic development is still a story waiting to be told. So far there is neither pride in the one-room schoolhouses' great achievements nor understanding of the significance of better education for 80 per cent of the population of rural Norway. The only evidence of the one-room schoolhouse story is the many schoolhouses preserved in open-air school museums, but despite the numbers of these museums, the history of education does not seem to be emphasized; the schoolhouses are often closed and not integrated in guided tours. The importance of school reform for social, cultural and economic development, even in the museums, is a neglected area.

\subsection{The need for a shared symbol}

The stories told in the Norwegian schoolhouse museums, for those able to get into these often closed buildings, are the stories communicated by pictures and paintings in the classrooms. There is, however, no evidence that there were any pictures inside the classrooms in the nineteenth century. Only in the post-World War II period, a period characterized by a revival of national patriotism, pictures of the King and Crown Prince and the surrender of the old castle in Oslo by the Germans were widely distributed to all schools. In the same period of revitalized nationalism, pictures of the Norwegian polar heroes, Amundsen and Nansen, and their vessels and airships, were distributed to schools and displayed in classrooms. In the same period pictures of Norwegian 
historical monuments, Norwegian romantic landscapes and pictures with religious motifs also appear in the schoolhouses, but the one-room schoolhouses never became a symbol of those values which the pictures in the classroom reflect, and the Norwegian national heroes and national identity were not linked to the small, rural schoolhouse: the classroom was merely used to promote these kinds of ideas.

The most valuable and appreciated Norwegian icon is raw, wild nature, as well as cultural historic landscapes, including old timber farmhouses. The people admired by Norwegians are those who were able to control this wilderness, whether the independent farmer or the adventurer who walked to the South Pole. These elements fit the national identity as it was established in the second half of the nineteenth century. Although school museums display pictures showing these historic national icons, these elements do not have a special affiliation to historic schools and their significance is not dependent on or linked to the one-room schoolhouses either as an institution or as a historic monument. The national Norwegian icons were just part of the education which was passed on to new consolidated schoolhouses in the 1960s.

The one-room schoolhouses in Norway have not become institutions for national identity or common values. The story of the one-room schoolhouse is seldom told in Norway and, if it is, there are no sentimental or nostalgic reflections or pride. Neither do they function in important historical developments, either local or national. ${ }^{47}$ Even though some Norwegian papers, books and pamphlets address local school history, the one-room schoolhouse era is often mentioned in passing as a story of bygone times, a stepping-stone to modernity, better education and larger and more effective schools. In this context the one-room schoolhouses are simply unused houses, without substantial architectural values, whose purpose was to give the rural population a minimum of education - often against their will. The small schoolhouses in rural areas were not designated tobe a significant object of heritage andto represent the genuine Norwegian identity, nor did they reflect the virtues of the limited but distinguished urban community.

Jonathan Zimmerman wrote: 'We shape our buildings, and thereafter they shape us, and they continue to do so, long after the buildings themselves are gone, in the ways that we choose to remember them'. ${ }^{48}$ The words 'in the ways that we choose to remember them' show that the stories we are telling, the content of our books and papers, the artifacts displayed in schoolhouse museums and finally the schoolhouses we choose to preserve, reflect some selected memories - not reflections of historical realities. The story which is chosen to be told in the Midwest is the story of a common desire to build a nation, the story of the struggle to civilize the people of the West through education and upbringing, and the virtues and values once enshrined in the schoolhouses are not surprisingly the same virtues and values still appreciated in the Midwest. As Gulliford expressed it: 'The same populist spirit that sustained the pioneers in building these schools now sustains their descendants as they seek to preserve them' ${ }^{49}$ The different social and political contexts in which the schoolhouses were built, the motivation for the comprehensive effort of building them, and contemporary society's perception and interpretation of this history and their roles in present society explain the lack of preservation in Norway and the abundant presence in the American Midwest.

70 At least in Norway, the $19^{\text {th }}$ and early $20^{\text {th }}$ century project of developing a modern democratic society, including better education for the majority of the population, is not 
sufficient reflected in the governmental heritage practise. The authorized heritage discourse (AHD) has until recently first and foremost safeguarded the objects which were essential in the $19^{\text {th }}$ century nation building projects, or objects of outstanding, mostly architectural, values. This portrayal of modern society based on education and democracy, has so far not received symbolic value in Norway or Europe, as it has in the United States. It is perhaps too late to revive the ordinary common schoolhouse as a symbol in Europe but at least the stories told in the preserved schoolhouses should tell the story of the significance of the school reform and the important achievement of the small one-room schoolhouse rather than focusing on the primitive circumstances.

I wike to thank William L. Shermann of lowa for opening many schoolhouse doors in the Midwest to me. The Historical Societies of Wisconsin and Iowa provided generous support. I am also grateful to my colleagues Dr Wera Gran and Dr Inga Fløisand for their considerable help and support. This paper is based on a research project carried out and financed by The Norwegian Institute for cultural heritage research (NIKU).

\section{NOTES}

1. William L. Shermann, ed., Iowa's Country Schools: Landmark of Learning (Parkersburg, IA: MidPrairie Books, 1998), 5.

2. Jonathan Zimmermann,Small Wonder: The Little Red Schoolhouse in History and Memory (New Haven, CT: Yale University Press, 2009); Andrew Gulliford, America 's Country Schools (Washington, DC: Preservation Press, 1991); Wayne E. Fuller, One-Room Schools of the Middle West (Lawrence, KS: University Press of Kansas, 1994); Leidulf Mydland, 'Fastskoleloven 1860 og bygging av skolehus,' Årbok for norsk utdanningshistorie 23 (2006):117-37; Alfred Oftedal Telhaug and Odd Asbjørn Mediåas, Grunnskolen som nasjonsbygger (Oslo: Abstrakt forlag, 2003); Paul Theobald, Call School: Rural Education in the Midwest to 1918 (Carbondale and Edwardsville, IL: Southern Illinois University Press, 1995).

3. Sol Cohen, "The History of the History of American Education, 1900-1976: The Uses of the Past," Harvard Educational Review 46.3 (1976):298-330.

4. Ibid., 133.

5. Leidulf Mydland, 'Fra skolehus til kulturminne,' Årbok for Norsk utdanningshistorie 25(2008): 288-90.

6. Ned Kaufmann, Place, Race and Story (New York, NY: Routledge, 2009); Brian Graham and Peter Howard, eds., The Ashgate Research Companion to Heritage and Identity (Aldershot: Ashgate, 2008); Laurajane Smith, Uses of Heritage (London: Routledge 2006); Laurajane Smith, ed., Cultural Heritage:Critical Concepts in Media and Cultural Studies (London: Routledge, 2007); Angela Phelps, G.J. Ashworth, and Bengt O.H. Johansson, The Construction of Built Heritage (Aldershot: Ashgate, 2002); David Lowenthal, The Past is a Foreign Country (Cambridge: Cambridge University Press, 1985); Hayden White, The Content of the Form (Baltimore and London: John Hopkins University Press, 1987); Christopher D. Geist, 'Historic Sites and Monuments as Icons,' in Ray B. Browne and Marshall Fishwick, eds., Icons of America (Bowling Green, OH: Popular Press, 1978), 57-66.

European journal of American studies, 6-1 | 2011 
7. Zimmerman, Small Wonder, 172.

8. Gulliford, America's Country Schools, 35. Fuller, One-Room Schools, 1. Based on the US Bureau of Education Bulletin no.90 (1921), which shows the number of schoolhouse in 1918. According to the US Census Bureau, October 1995 the total population in the Midwest in 1920 was 34 million. Mydland, 'Fastskoleloven,' 117-137.

9. Fuller, One-Room Schools, 7.

10. Ibid.,15.

11. Ibid.,14.

12. Mydland, 'Fastskoleloven,' 117-137.

13. Ibid.

14. Hans Jørgen Dokka, Fra Allmueskole til folkeskole (Oslo:Universitetsforlaget, 1967),156.

15. Omgangsskole is difficult to translate, but means that for some weeks every year children would gather together in particular farms, where education took place under the supervision of a teacher who would move from farm to farm.

16. Mydland, 'Fastskoleloven,' 119.

17. Fuller, One-Room Schools, 2; Urban J. Wayne, and Wagoner L. Jennings Jr., American Education: A History (London: Routledge, 2009),196ff; C. Golding and Lawrence F. Katz, The 'Virtues' of the Past: Education in the First Hundred Years of the New Republic. Working papers series (Cambridge, MA: National Bureau of Economic Research, 2003), with references to unpublished paper by Peter Lindert (2000).

18. Shermann, Iowa's Country Schools; Theobald, Call School: 17; William H. Dreier in William L. Shermann, ed., Iowa's Country Schools: Landmark of Learning (Iowa: Mid-Prairie Books 1998), 3; Grace S. Schoerner ed., Under The Roof: A Traveler's Guide to America's One-room Schoolhouse Museums (Pine, AZ: Pine-Strawberry Archeological \& Historical Society, 2000).

19. Theobald, Call School, 96.

20. http://www.countryschoolmovie.com./Fourth Wall Films, Moline, IL.

21. Paul, Rocheleau, The One-room Schoolhouse: A Tribute to a Beloved National Icon (New York, NY: Universe, 2003); Zimmermann, Small Wonder.

22. Zimmermann, Small Wonder,160.

23. Fred E. H. Schroeder, 'The Little Red Schoolhouse', in Browne and Fishwick, Icons of America, 139.

24. Jessica Conley and Mark Dewalt, 'The One-Room School Goes to College' (paper presented at the Country School Association of America Conference, Miami University, Oxford, Ohio, June 2008). Published in www.cedu.niu.edu/blackwell/1roomschool_locations.html (3 January 2008)

25. Barbara A. Mitchell, Iowa's Historic Schools. http://www.iowahistory.org/ historic-preservation/statewide-inventory-and-collections/

schools/. State Historical Society of Iowa. Des Moines, IA. November, 2010.

26. These were Lincoln Elementary School in Dubuque, North River Stone School in Madison County, Stone School in Scott County, Pleasant Hill School 'Little red school house' in Wayne County, Canton School in Iowa County, Goldenrod School in Page County, and finally Locust School in Winneshiek County.

27. Beach School, Linn County, listed in 1982.

28. Mann School, Monona County, listed in 2001.

29. The number is based on a rough survey done in June 2008.

30. All quotations taken from the NRHP.

31. Camilla Deiber, Peggy Beedle, and Kris Hirs, eds., Country Schools for Iowa (Hiawatha, IA: Louis Berger, 2002).

32. State Historical Society of Iowa, home page. 
33. Norwegian register of buildings protected by law: wwW.Askeladden.no (November 2010).

34. Smith, Uses of Heritage.

35. Mydland, 'Fra skolehus til kulturminner.'

36. Leidulf Mydland, 'Skolehus på museum,' Årbok for Norsk utdanningshistorie 26 (2009):287.

37. Dokka, Fra Allmueskole 1967; Einar Høygård, and Herman Ruge, Den norske skoles historie (Oslo: Cappelens forlag, 1963); Telhaug and Mediås, Grunnskolen, 2003; Mydland, 'Fastskoleloven'.

38. Peter Flora, ed., The Theory of Stein Rokkan (Oxford: Oxford University Press, 1999),108.

39. Telhaug og Mediås, Grunnskolen, 2003; Rune Slagstad, De nasjonale strateger (Oslo: Pax forlag A/ S 2001), 389; Svein Lorentzen, Ja, vi elsker ... Skolebøkene som nasjonsbyggere 1814-2000 (Oslo, Abstrakt forlag, 2005); Lawrence A Cremin, The Transformation of the School, progressivism in American Education 1876-1957 (New York: Alfred A. Knopf, 1962); Howard Zinn, APeople's History of The United States (New York: Harper Collins Publisher, 1980); Norwegian translation, 'USA, Folkets Historie' (Oslo: Oktober Forlag, 2006); Stuart J. Foster, 'The struggle for American identity: treatment of ethnic groups in United States history textbooks,' History of Education 28.3 (1999):351; Keith C Barton, 'History Education and National Identity in Northern Ireland and the United States: Differing priorities'. Theory into practice. Vol. 40, Number 1. (College of Education: The Ohio State University, 2001); Jeffrey Mirel, 'Civic education and Changing Definitions of American identity, 1900-1950,' Educational Review 54.2 (2002).

40. Zimmermann, Small Wonder.

41. Ibid.

42. Ibid., 182 .

43. Norma C. Wilson and Charles L. Woodard, One-Room Country Schools: South Dakota Stories (University Station, Brookings, SD: South Dakota Humanities Council, 2001).

44. Sherman, Iowa's Country Schools, v.

45. Gulliford, America's Country Schools, 5 .

46. Smith, Uses of Heritage.

47. Mydland, 'Fra skolehus til kulturminne.'

48. Zimmerman, Small Wonder, 55, based on a statement by Winston Churchill.

49. Gulliford, America`s Country Schools.

\section{ABSTRACTS}

In the history of education the one-room schoolhouse has played an important role in several countries. In the rural areas of the US Midwest and in Norway the one-room schoolhouse was the most common school in the second half of the nineteenth century and the first decades of the twentieth. Although the schoolhouses at first sight seem identical there are some interesting points of distinction in their educational history and how their legacy is interpreted, managed, preserved and promoted today. In the Midwest they are a beloved national icon, often listed, embodying national values and virtues. In Norway their story is effectively untold, not a single one is listed on national preservation lists and by no means do they embody national identity, virtues or values. This article offers an explanation for this different treatment. 
INDEX

Keywords: Cultural heritage, education history, Midwest and Norway., one-room schoolhouse, preservation

\section{AUTHOR}

\section{LEIDULF MYDLAND}

Leidulf Mydland is a researcher at the Norwegian Institute for Cultural Heritage Research, Oslo, and head of the building department. He spent several years in heritage management as an archaeologist and building preserver and his primary research interest is in management of cultural heritage and the relation between local participation and state heritage authorities. 